\title{
Soil bioengineering for risk mitigation and environmental restoration in a humid tropical area
}

\author{
A. Petrone and F. Preti \\ DEISTAF - Center for biosystems and agroforestry engineering, University of Florence, Florence, Italy \\ Received: 6 July 2009 - Published in Hydrol. Earth Syst. Sci. Discuss.: 29 July 2009 \\ Revised: 19 January 2010 - Accepted: 24 January 2010 - Published: 8 February 2010
}

\begin{abstract}
The use of soil bio-engineering techniques in developing countries is a relevant issue for disaster mitigation, environmental restoration and poverty reduction. Research on the autochthonal plants suitable for these kinds of interventions and on the economic efficiency of the interventions is essential for the dissemination of such techniques. The present paper is focused on these two issues as related to the realization of various typologies of soil bioengineering works in the humid tropics of Nicaragua.

In the area of Río Blanco, located in the Department of Matagalpa, soil bioengineering installations were built in several sites. The particular structures built were: drainages with live fascine mattress, a live palisade, a vegetated live crib wall for riverbank protection, a vegetative covering made of a metallic net and biotextile coupled with a live palisade made of bamboo. In order to evaluate the suitability of the various plants used in these works, monitoring was performed, one on the live palisade alongside an unpaved road and the other on the live crib wall along a riverbank, by collecting data on survival rate and morphological parameters. Concerning economic efficiency, we proceeded to a financial analysis of the works. Once the unit price was obtained, we converted the amount into EPP Dollars (Equal Purchasing Power) in order to compare the Nicaraguan context with the European one.

Among the species used we found that Gliricidia sepium (local common name: Madero negro) and Tabebuia rosea (local common name: Roble macuelizo) are adequate for soil bioengineering measures on slopes, while Erythrina fusca (local common name: Helequeme) resulted in successful behaviour only in the crib wall for riverbank protection.
\end{abstract}

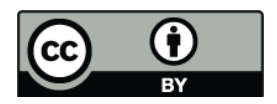

Correspondence to: A. Petrone (alessandro.petrone@unifi.it)
In comparing costs in Nicaragua and in Italy, the unit price reduction for Nicaragua ranges from 1.5 times (for the vegetative covering) to almost 4 times (for the fascine mattress), using the EPP dollar exchange rate.

Our conclusions with regard to hydrological-risk mitigating actions performed on a basin scale and through naturalistic (live) interventions are that they are not only socially and technically possible, even in hardship areas (by maximizing the contribution of the local labour force and minimizing the use of mechanical equipment), but also economically sustainable.

\section{Introduction}

It is well known that soil bioengineering entails the use of live materials, specifically plant parts (cuttings, roots and stems), which serve as the main structural and mechanical elements in a slope protection system (Schiechtl, 1985). Live plants and other natural materials have been used for centuries to control erosion problems on slopes in different parts of the world. These natural remedies became less popular with the arrival of the Industrial Revolution (Gray and Leiser, 1982; Gray and Sotir, 1996; Evette et al., 2009).

The stabilization of slopes through vegetation and soil treatment measures may be particularly appropriate in situations where an abundance of vegetative materials is present, and where manual labour, rather than machinery for installation, can be easily found (Schiechtl, 1985). It is particularly important to understand if when faced with bank or slope instability situations it is possible to intervene with methods that can be adopted by user communities (e.g. Garrity et al., 2004).

In order to evaluate the transferability of soil bioengineering techniques, the situation in so-called developing countries is analyzed, evaluating the indications given by major international cooperation agencies. For example, FAO

Published by Copernicus Publications on behalf of the European Geosciences Union. 
publications consider this technology to be the most appropriate for watershed management, landslide prevention measures, vegetative and soil treatment measures and, generally, in land reclamation (Costantinesco, 1976; Sheng, 1977a, b, 1979, 1990; Bostanoglou, 1980; Marui, 1988; Schiess, 1994).

Currently, soil bioengineering is largely applied in mountainous areas of Europe and North America (Evette et al., 2009), providing a large quantity of data that enables safe planning for similar interventions. Since in developing countries only a few examples of such interventions can be found, it is important to stress their future use according to the concepts of technology transferring and sustainable development (Anaya et al., 1977; Clyma et al., 1977; Dickerson and Lake, 1989).

During the last few years the employment of naturalistic rehabilitation techniques in the rural communities of developing countries has attracted the growing interest and involvement of a number of European research groups, whose investigative task is to identify the suitable plant species to be used in each geographical setting (Castillo and MüllerSämann, 1996; Clark and Hellin, 1996; Burch and Lopez, 1999; Florineth, 2004; Ghimire and Karki, 2004; Sutili et al., 2004; Lammeranner et al., 2005; van Beek et al., 2005; Petrone and Preti, 2005; Bimala et al., 2006; Li et al., 2006; Petrone et al., 2006; Preti, 2007; Reubens et al., 2007; Petrone and Preti, 2008; Evette et al., 2009; Zanoni, 2009). Terraces have been the basis of agriculture in hilly tropical areas since ancient times and in the case of contour barrier hedgerows, technicians have now learned to discard complex and relatively costly systems, which have been increasingly rejected by farmers and modified into cost-cutting "natural vegetative strips" (e.g. in the Philippines, Garrity et al., 2004).

In a previous study (Petrone and Preti, 2008), we presented the experience we gathered during our work in León, Nicaragua. This experience confirmed both the technical feasibility of various types of soil bio-engineering interventions and the interest of the municipalities involved. We worked in an urban context where it was possible to operate only along local rivers. Furthermore, the socio-economic conditions were quite different from those in the rest of the country, in terms of both the living conditions of the population and the greater availability of materials needed for the operations. For all these reasons, the opportunity of extending the zone of intervention to the mountain and rural areas was approved with interest by the whole team.

The DIPECHO (Disaster Preparedness Echo) program is specifically aimed at implementing activities for improving the reactivity of local communities to natural disasters such as floods, landslides, earthquakes, and volcanic eruptions. However, interventions for mitigating small-scale risks are planned as well. These interventions are aimed at promoting good practices for disaster mitigation. It is from such a perspective that the activities outlined in the present chapter were performed. They did not consist solely in performance of the operations and related training, but also in both the subsequent monitoring and analysis of their financial sustainability.

The aim of the work is to demonstrate that soil bioengineering stabilization interventions are the most appropriate, because they are in accordance with the main concept of sustainable development, thanks to the use of local labour, local materials and the reproducibility of the intervention typologies.

The paper is structured as follows: in Sect. 2 we describe the study area, the involvement of local communities, the plants used and the implementation of the experimentation with monitoring and cost analysis. The results obtained are presented in Sect. 3 on the basis of the case studies (cuttings performance and statistical analysis, financial evaluation of the interventions); finally, these results are discussed and conclusions are drawn in Sects. 4 and 5.

\section{Materials and methods}

\subsection{Area description}

The town of Río Blanco is located in the Department of Matagalpa, in central Nicaragua, $110 \mathrm{~km}$ east of the city of Matagalpa (the capital of the department bearing the same name) and $250 \mathrm{~km}$ north-west of Managua, the nation's capital (Fig. 1). Río Blanco covers an area of $700 \mathrm{~km}^{2}$ with a population density amounting to 47 inhabitants $/ \mathrm{km}^{2}$. (AMUNIC-INIFOM, 1997).

The economy is based mainly on cattle breeding and agriculture. Nonetheless, it is the former of these two activities that is absolutely predominant.

Although the town's roads are in bad condition, a good paved road links it to the capital. In fact, the absence of viable road links is a problem for rural communities: almost all of them must be reached by rugged four-wheel drive vehicles, and in some cases traveling is feasible only during the dry season.

Río Blanco is characterized by a humid tropical climate; its rainy season lasts 9 months (precipitations range from $2400 \mathrm{~mm}$ to $2600 \mathrm{~mm}$ per year) and the average temperature ranges between $20^{\circ}$ and $26^{\circ}$. Rain peaks occur during July and August.

From an ecological standpoint, the area where Río Blanco lies, between the Atlantic and the Pacific belt, has been threatened by deforestation carried out to create pasture lands, to remove woodland and obtain arable land. It was in response to this phenomenon that in 1991 the reserve of the "Cerro Musún" was founded, with a territory of 4778 hectares and elevations from 300 to $1438 \mathrm{~m}$ a.s.l. The Cerro Musún is made up of over 60 million-year-old volcanic rocks forming peaks which characterize the reserve. 


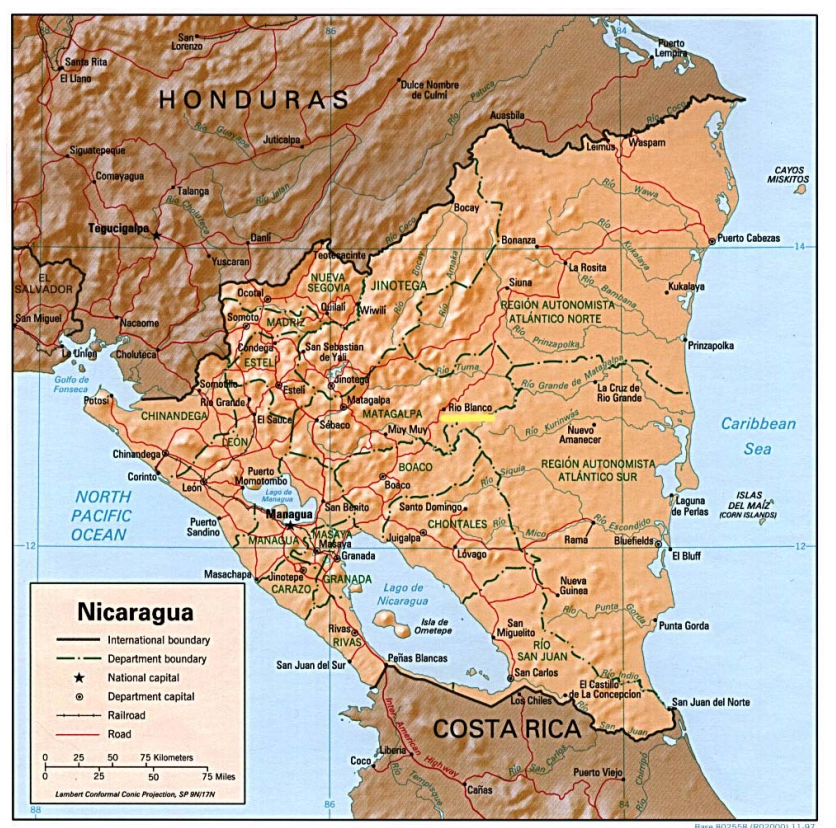

Fig. 1. Location of the town of Río Blanco (http://upload. wikimedia.org/wikipedia/commons/c/c0/Nicaragua_rel_97.jpg.

The protected area was the object of studies focusing on identifying the local biodiversity rate. Thanks to them, 284 species were identified, half of which were plant and the other half animal.

The typical vegetation of this area is represented by humid sub-tropical broad-leaved woods as well as by mountain woods.

According to the classification introduced by the Central American Hydrologic Project (Alcaldía Municipal de Río Blanco et al., 2005), the area is inside basin n.55 (Fig. 2), known as the "Río Grande De Matagalpa Basin". The town's territory includes the sub-basins of the meander shaped rivers Tuma, Paiwas and Wanawana.

Some of the waterways crossing the area are northbound and drain into the Río Tuma, while those flowing south (among them the Río Blanco, which has given its name to the town) drain into the Río Paiwas. It is from the area of Cerro Musún that seven of the twenty four sub-basins flowing through the town originate. Their streams all bring a year-round water discharge.

Geologically, volcanic rocks resulting from violent eruptive phenomena in the past are emblematic of the area. The landscape is characterized by mountains ranging between 80 and $1438 \mathrm{~m}$ a.s.l. (the average is about $500 \mathrm{~m}$ a.s.1.) and whose average slope is more than $50 \%$.

Data from 2003 concerning land use are reported on Table 1 . The aforementioned important role of cattle-breeding for the economy is self-evident. Pastures are often on steep slopes, a fact which not only favours the waste of fertile soil, but also increases the formation of marked erosive processes.

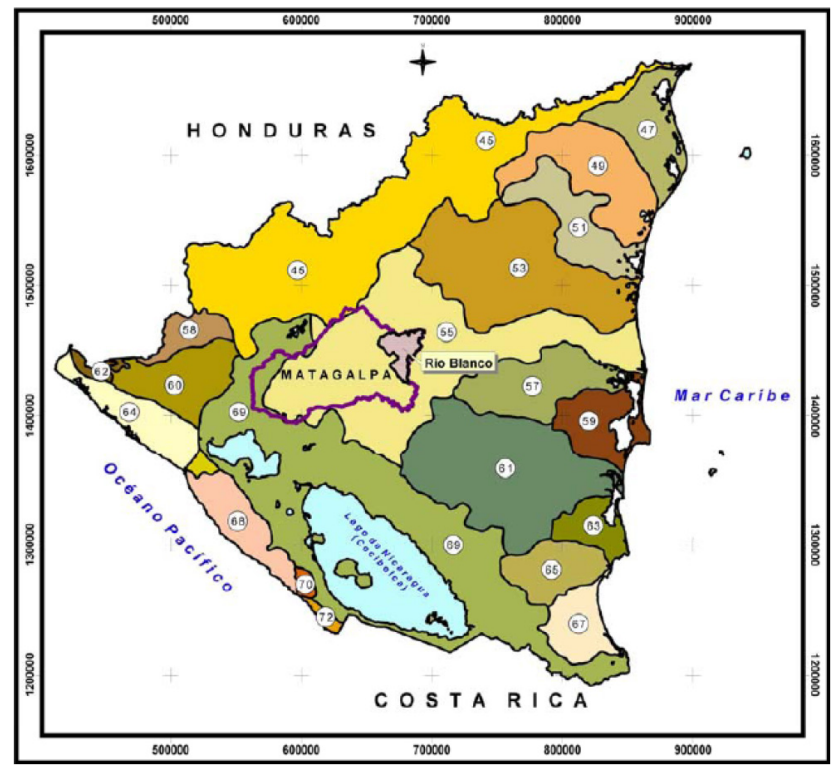

Fig. 2. Nicaraguan hydrographic basins (Alcaldía Municipal de Río Blanco et al., 2005).

A few words should be spent on the question of the potential land use, i.e. of the activities which should be developed locally with full respect for the vocations of the different areas. As mentioned above, types of land use should be properly distributed, as shown in the Table 2.

It is easy to see how serious the problem of land use is in the Río Blanco region (although the situation is paradigmatic of the whole country): the concentration of the land in the hands of a few large landowners leads to the formation of enormous pastures at the expense of an integrated use of the woodlands, both from a productive point of view (agroforestry and silvopastoral) and a land-protection point of view. This situation creates a lack of balance in each of the three axes of what is called "sustainable development": economic, social and environmental. Moreover, it causes problems for the poorest part of the population, who in order to assure provisions of food and wood lay themselves open to accusations of exploiting natural resources inappropriately for their survival. Often the response is to establish protected areas. However, these are frequently imposed from above and without any real dialogue with the interested parties, who therefore see themselves as being deprived of resources essential for their livelihood. This is what happened in Río Blanco as well. Indeed, before enacting policies for land protection it would be better to establish negotiations with landowners to work out a policy of land use conversion more in line with eco-compatible productivity models, such as agroforestry and silvopastoral systems, not to mention enacting serious land reform for more equitable land distribution. 
Table 1. Present land use in the town of Río Blanco (Alcaldía Municipal de Río Blanco et al., 2005).

\begin{tabular}{ll}
\hline Type of land use & Percentage of total (\%) \\
\hline Woods & 24.19 \\
Pastures & 72.30 \\
Cultivated land & 3.28 \\
Urban land & 0.23 \\
\hline
\end{tabular}

\subsection{The involvement of local communities in defining and implementing the project}

The methodology scheme adopted includes two general fields of analysis: the first is related to technical aspects and the second to the potential involvement of the single farmer or the farming community.

Through joint experimentation with the people, beneficiaries received training and experience in the design, implementation and evaluation of experiments. In this way their capacity for innovation can be substantially increased.

It is important to understand that for farmers to accept soil conservation technologies, the technology has to enhance yields (FEDERACAFÉ and CENICAFÉ, 1975; Hudson, 1982; Kirby and Morgan, 1984; Bunch and Lopez, 1999; Bruscoli et al., 2001; Suarez Diaz, 2001; Johnson et al., 2003; Nygren, 2005; Vishnudas et al., 2006). It is the increase in yield that convinces the farmers of the value of soil conservation, more than disaster mitigation or prevention and environmental restoration. If yields have increased or costs have decreased, artificial incentives are not required. On the other hand, if yields have not increased, no artificial incentive will make the adoption of the technology sustainable (Wilken, 1987; Rivera and Sinisterra 2006).

The main goal of the working methodology we used was to reach the highest possible level of involvement of local communities in each step of the proposed activities (Chambers, 1992; Leach et al., 1999; Bruscoli et al., 2001; Nygren, 2005; Olivier de Sardan, 2005; Petrone, 2006). We wanted to avoid that the people's part in future repetitions of the project would be merely "mechanical". Instead our goal was to offer them a clear overall vision of the whole series of efforts to be made, so as to enable them to carry on the project on their own with the aim of reaching a definitive solution.

Thus, the work proceeded according to the following steps:

- pre-selection of possible sites by the soil bioengineering experts, supported by both the project's personnel and the leaders of the various communities; the main criteria used for the choice were the communities' perception of the work's utility and the site's accessibility;
Table 2. Potential land use in the town of Río Blanco (Alcaldía Municipal de Río Blanco et al., 2005).

\begin{tabular}{ll}
\hline Type of land use & Percentage on total $(\%)$ \\
\hline Woods & 73.05 \\
Pastures & 20.71 \\
Cultivated land & 4.62 \\
Protected areas & 1.37 \\
Urban land & 0.25 \\
\hline
\end{tabular}

- purchase of the needed instruments and materials;

- theoretical education on soil bio-engineering techniques imparted to the inhabitants of the three selected communities (Río Blanco, Wanawas e La Isla). During these events we submitted the selected sites to the judgment of the Communities and we received positive feedback. Then we organized the work to be done both logistically and in terms of labour supply. A particularly noteworthy aspect was that a two-way learning experience occurred: since the Italian experts did not know what plant species were the most suitable in those sites, it was the local communities that provided this information. Thanks to the close relationship they still have with their natural surroundings, they were able to indicate the best species in terms of cutting reproduction.

- signing of a Cooperation Agreement with the local institutions of the selected communities on the implementation of the various phases of the project;

- collection of both living vegetative material (live cuttings and pegs) and inert matter (stones, ground, etc.) around the intervention sites, and then beginning the work.

The project covered the costs for the purchase of the needed materials, tools and equipment (which were donated to the communities afterwards), as well as for the planning and management of the work, while the communities gave their contribution by providing the labour force and vegetative materials.

\subsection{Plants used}

After holding meetings with local communities, the list of the species to use as cuttings was drawn up. The following criteria were used to choose the plant species (Petrone and Preti, 2008):

- local plants;

- easily found in the area concerned;

- shoot propagation; 
- high tolerance of differing soil conditions;

- not too large once adult.

With these factors in mind, the following species were chosen:

- Erythrina fusca (Lour.) (local common name: Helequeme);

- Gliricidia sepium (Jacq.) Steud (local common name: Madero negro);

- Tabebuia rosea (Bertol.) DC (local common name: Roble macuelizo).

The following is a brief description of the above-cited plants:

Erythrina fusca, member of the Fabaceae family, is a deciduous tree thickly branched which at its mature stage can reach $20 \mathrm{~m}$ in height and about $40 \mathrm{~cm}$ in diameter. It is a pioneer species which, in the wild, is frequent in areas subjected to periodic flooding and along streams and waterways, generating pure stands. It requires average precipitations between 1500 and $3000 \mathrm{~mm}$ per year and average temperatures between 16 and 24 degrees. It is native to the humid tropics of Central and Southern America. It is the species with the widest distribution within the genus of Erythrina, as it can grow at any altitude between 0 and $2000 \mathrm{~m}$. Erythrina fusca is commonly used as a shadow tree in coffee and cacao plantations, but it is also used for firewood, fodder and healing (IRENA, 1992);

Gliricidia sepium is a member of the Fabaceae family. It is a small-to-medium-sized tree, reaching heights between 6 and $20 \mathrm{~m}$ (10 m on average), very common in Mexico and Central America. It grows well with a temperature of 20$30^{\circ} \mathrm{C}$, with precipitations between 900 and $1500 \mathrm{~mm}$ per year and a five-month dry season. It is used for firewood, fodder and healing (Petrone and Preti, 2008);

Tabebuia rosea, member of the Bignoniaceae family, is a medium-sized tree (it can reach $20 \mathrm{~m}$ in height), with a straight trunk and a wide, irregular crown. As far as soil is concerned, it is not very exacting. It has good climatic adaptability, and it easily colonizes untended fields. It is native to central-southern America and is very common all over the territory of Nicaragua. Its red wood is highly appreciated in carpentry for furniture manufacture. Tabebuia rosea is also used for ornamental and healing (IRENA, 1992).

The choice of the species was made first of all by asking the local population which plants had the characteristics described above. In the study area it was rather easy to detect these species with the help of the local population. Actually, it is common use to make "cercas vivas" (in English "live fences") by driving cuttings into the soil and then fencing them with wire. Obviously, the species used for this purpose are easily found in the area; they propagate from cuttings with excellent results, and once adult not only can they be used for fencing, but they also provide wood and, in some cases, fodder. As a matter of fact, the plants suggested for our project by the population had previously been selected by them for their general utility; our job was now to understand which of these plants also have characteristics fitting soil bioengineering aims.

\subsection{Implementation phase: jobs carried out at various sites}

Soil bio-engineering installations were built in several sites inside the town of Río Blanco during a time period which started on 12 January 2006 and lasted until 26 February 2006. The particular structures built were:

- Drainages with live fascine mattress (La Isla site)

- A live palisade (La Isla site) (Fig. 9)

- A vegetated live crib wall for riverbank protection (Wanawas site) (Fig. 11)

- A covering made of a metallic net and biotextile coupled with a live palisade made of bamboo (Río Blanco)

The vegetated live crib wall was set up after having first run a check for its stability against capsizing and sliding; this verification procedure produced satisfactory results, with a safety factor equal to 2.3 .

Data sheets concerning every job were compiled with the dual purpose of describing the general features of the work performed and serving as a basis for future monitoring. The sheets' structure was based on the model proposed by Tuscia University with regard to censuses of soil bioengineering jobs in the region of Latium (Preti, 2006; Regione Lazio, 2006; Preti and Milanese, 2007), although some modifications were made to adapt the sheet to the local setting.

As explained in the following paragraph, only the live palisade and the live crib wall have been monitored. For this reason we describe only these sites in detail. La Isla site, where the live palisade was set up, is located at $420 \mathrm{~m}$ a.s.l.; its exposure is east-northeast and its soil texture is silty clay loam. The Wanawas site, where the live crib wall was constructed, is situated at $180 \mathrm{~m}$ a.s.l., with an east-southeastly exposure and loamy sand soil texture.

In the live palisade the initial size of the Erythrina fusca, Gliricidia sepium and Tabebuia rosea plants were $1-5 \mathrm{~cm}$ in diameter and $0.9 \mathrm{~m}$ in length, whereas in the live crib wall, where only Erythrina fusca was used, the sizes where 2$7 \mathrm{~cm}$ in diameter and $1.8 \mathrm{~m}$ in length. All the cuttings were collected in the immediate surroundings of the installations; as a matter of fact Erythrina fusca, Gliricidia sepium and Tabebuia rosea are often used for live fences in the area (and of course they are also very common in the wild). 


\subsection{Monitoring and statistical analysis}

The following are the parameters we applied in measuring and monitoring the planted cuttings of the various installations (Lammeranner et al., 2005; Petrone and Preti, 2008):

- survival rate, which is basically the percentage of cuttings that spawn shoots;

- length of terminal shoot (in both monitorings);

- diameter at the base of terminal shoot (only in the last monitoring).

The second parameter is particularly important because it is directly correlated to the development of the rooting system. Therefore, this property shows the ability of the cuttings to serve as retainers of the soil's superficial layer. As such, it constitutes an important element for soil reinforcement. On the other hand, the diameter of the terminal shoot is important, as it is connected to the flexibility of the shoot itself: above $4 \mathrm{~cm}$ the shoots show a reduced capacity to bend at the passage of the flow of water, and consequently their efficacy in bank stabilization is also reduced (Regione Lazio, 2006; Preti et al., 2010). The first monitoring was performed in March 2007 and the second in September 2007. We consider the data resulting from the monitoring of the live crib wall and from the live palisade, as the vegetative covering with biotextile and metallic net gave unsatisfactory results owing to the lack of extra irrigation immediately after planting (only one out of the 4 species, the Gliricidia sepium, survived with $10 \%$ of specimens). Moreover, owing to its intrinsic characteristics, the live mattress does not allow quantitative monitoring of the rooting percentage of the cuttings employed.

The collected data have been used in performing statistical tests to verify the following hypotheses:

- the various species have different survival rates;

- the development of the apical shoot is characteristic for every species;

- the development of the diameter of the shoots is characteristic for every species;

- both the survival and the development of a cutting depend on the installation where it was inserted.

\subsection{Analysis of soil bioengineering intervention sustainability}

The economic sustainability of risk-mitigating interventions in so-called developing countries is a highly important issue. Therefore, we decided to perform a careful financial analysis of our work, trying not to overlook any of the diverse components that make up the final price. In particular, we dealt with expense entries as follows:

- Labour force: as the project designers were on site every day to supervise the works, it was not difficult to assess the actual time needed (according to the working conditions imposed by the local context) to complete the various jobs;

- Materials: we filed all purchase invoices by matching each one of them to the installation job it related to; the materials offered by the Communities (e.g. the cuttings) were considered as their contributions and assessed at local market prices;

- Rentals: in this case as well we used the agreements stipulated with the various parties (often belonging to the informal economy).

Thus we decided to follow the price-analysis scheme adopted by the Soil Bio-engineering Manual of the Latium Region (Regione Lazio, 2006). Sometimes it was adapted to the differing needs and circumstances encountered.

Once the unit price was obtained, we converted the amount to EPP Dollars (Equal Purchasing Power). EPP is an artificial dollar whose purchasing power is equal in all countries, as its value corresponds to the weighted average of the world prices of 151 kinds of goods. This instrument is commonly used by international Organizations such as UNDP (UNDP, 2006) and the International Monetary Fund, to mention only a few. It is a way of comparing prices paid in different geographic areas and understanding their actual entity (Petrone and Preti, 2008).

\section{Results}

\subsection{Cuttings performance and statistical analysis}

On the whole, the survival rate of the cuttings was $45 \%$ after 12 months and $37 \%$ after 18 months. As far as the individual species are concerned, the registered survival rates after 18 months from installation of the live palisade were:

- Erythrina fusca: $14 \%$

- Tabebuia rosea: $63 \%$

- Gliricidia sepium: $100 \%$

The Chi-square test $(d f=2, p=0.01)$ revealed that the differences between the survival rates of the three species are statistically significant. If a deeper analysis of the Chi-square table is performed, we discover that two values, the percentage of living cuttings of Tabebuia rosea and Gliricidia sepium, give $66 \%$ of the total value for the Chi-square test. A comparison between the observed and expected values shows that the significativity is largely caused by the high percentage of living cuttings of the two species.

The survival rate of Erythrina fusca in the live crib wall was considerably higher, reaching $42 \%$ after 18 months from planting. The Chi-square test $(d f=1, p=0.01)$ revealed that the difference between the survival rates is statistically significant. 


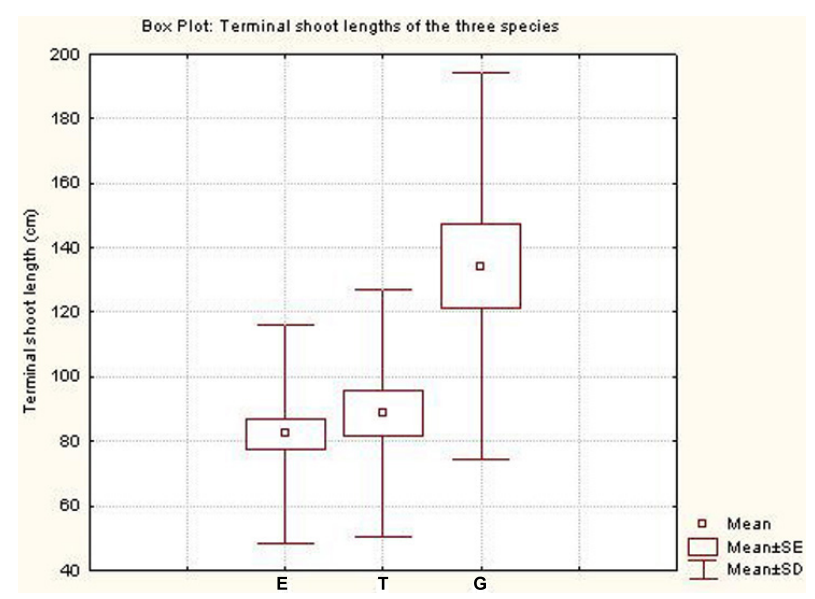

Fig. 3. Terminal shoot length for Erythrina fusca (E), Tabebuia rosea $(\mathrm{T})$ and Gliricidia sepium $(\mathrm{G}) 18$ months after the construction of the live palisade.

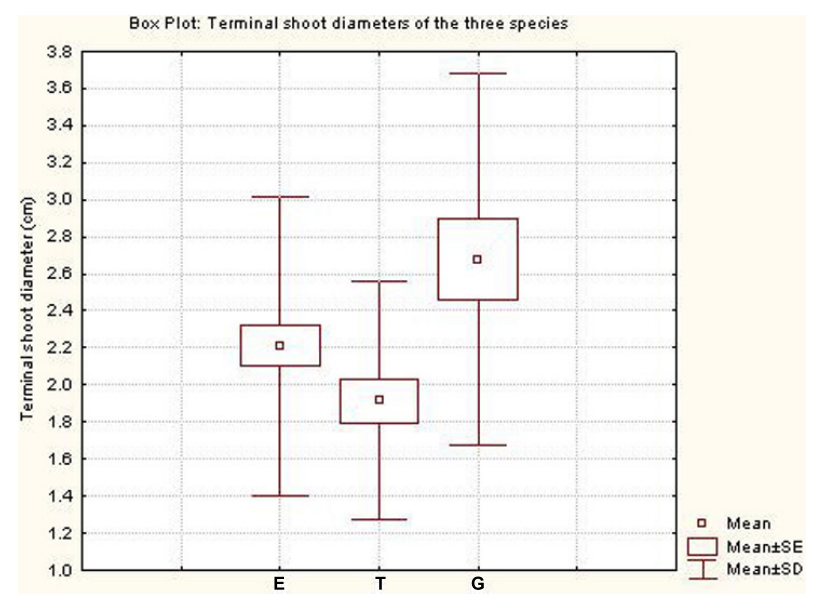

Fig. 4. Terminal shoot diameter for Erythrina fusca (E), Tabebuia rosea $(\mathrm{T})$ and Gliricidia sepium (G) 18 months after the construction of the live palisade.

As far as the development of the terminal shoots is concerned (see Fig. 3 and Table 4), the Gliricidia sepium resulted as the species with the highest growing rate, while Erythrina fusca and Tabebuia rosea showed comparable results. Due to inhomogeneity of variance a Kruskal-Wallis test instead of an Anova test was used and showed that the differences between the three species in the case of terminal shoots length are statistically significant $(p=0.01)$.

The Least Significant Difference test yielded the following results: as far as the development of the terminal shoots is concerned, there are no significant differences between Erythrina fusca and Tabebuia rosea $(p=0.05)$, while the differences between the length of the shoots of Gliricidia sepium and both Erythrina fusca and Tabebuia rosea are significant $(p=0.05)$.

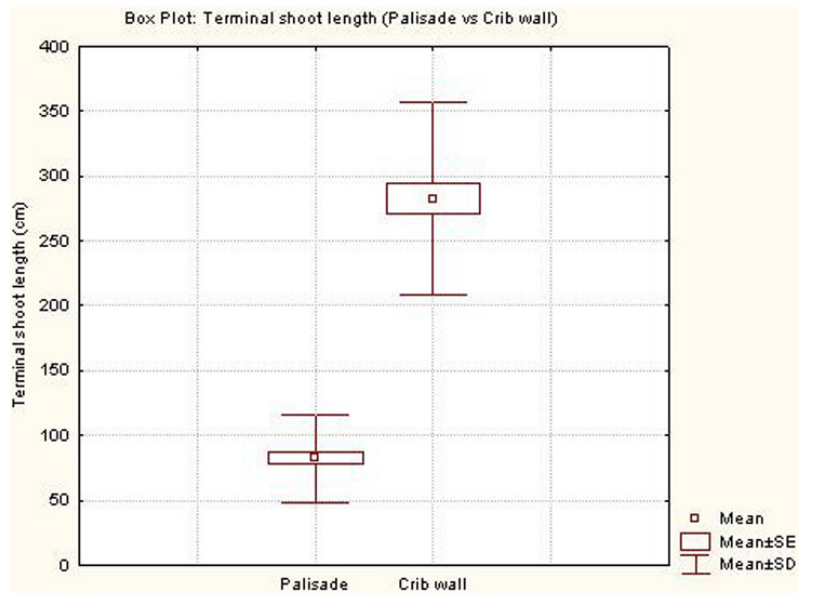

Fig. 5. Comparison between terminal shoot length of Erythrina fusca in the live palisade and in the live crib wall 18 months after the construction.

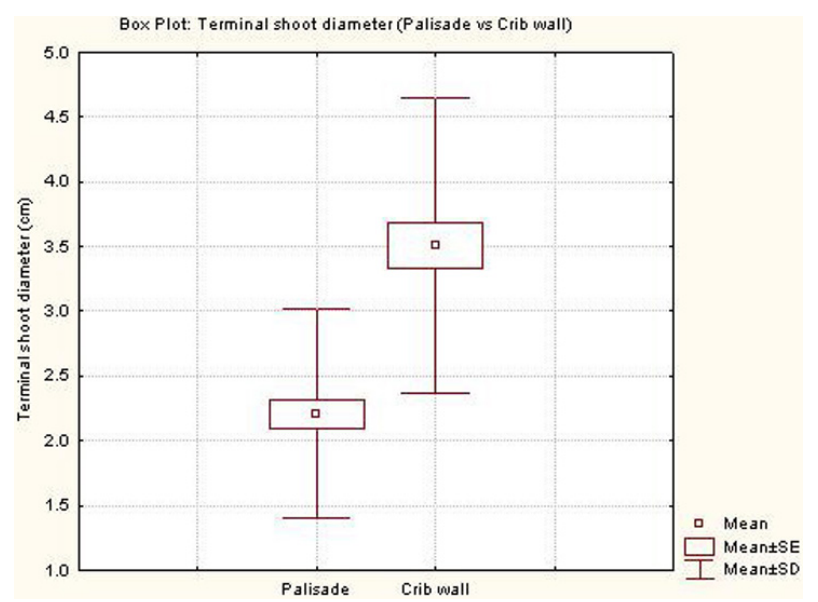

Fig. 6. Comparison between terminal shoot diameter of Erythrina fusca in the live palisade and in the live crib wall 18 months after the construction.

Also as far as the diameter of the shoots is concerned (Fig. 4), Gliricidia sepium showed the highest growing rate. Post-hoc comparisons using the Turkey- Kramer test (performed after an ANOVA test that had showed a statistically significant difference between the three means) yielded the following result: the only difference statistically relevant in the diametrical growth is the one between Gliricidia sepium and Tabebuia rosea $(p=0.05)$.

The analysis between the different growing rates of Erythrina fusca's terminal shoots in live palisade and live crib wall, realized through a $\mathrm{t}$ Welch test with the Satterthwaite method (due to inhomogeneity of variance a t Student test could not be used), showed the following results: the difference between the observed means is significant for $p=0.01$, both for the length and the diameter of the terminal shoots (see Figs. 5 and 6). 
Table 3. Ratio between construction costs in Italy and Nicaragua as a function of the adopted exchange rate.

\begin{tabular}{lrr}
\hline & $\begin{array}{r}\text { Ratio between fulfillment } \\
\text { costs in Italy and Nicaragua } \\
\text { (official exchange rate) }\end{array}$ & $\begin{array}{r}\text { Ratio between fulfillment } \\
\text { costs in Italy and Nicaragua } \\
\text { (EPP dollar exchange rate) }\end{array}$ \\
\hline Live fascine mattress on slope & 16.66 & 3.95 \\
Live palisade & 9.85 & 1.90 \\
Live crib wall & 13.15 & 2.53 \\
Vegetative covering with & 8.02 & 1.54 \\
metallic net and biotextile & & \\
\hline
\end{tabular}

Table 4. Length and diameter of terminal shoot (mean \pm standard deviation) for the different species in both sites 18 months after the construction.

\begin{tabular}{lcccc}
\hline & \multicolumn{2}{c}{ Erythrina fusca } & \multirow{2}{*}{ Tabebuia rosea } & Gliricidia sepium \\
\cline { 2 - 3 } & Live palisade & Live crib wall & & \\
\hline Number of plant replicates & 50 & 50 & 50 & 50 \\
Length $(\mathrm{cm})$ & $82.33 \pm 34.01$ & $282.76 \pm 74.64$ & $88.69 \pm 38.52$ & $134.14 \pm 59.90$ \\
Diameter at the base $(\mathrm{cm})$ & $2.21 \pm 0.81$ & $3.51 \pm 1.14$ & $1.91 \pm 0.64$ & $2.68 \pm 1.01$ \\
\hline
\end{tabular}

\subsection{Financial analysis of the project's implementation stage}

Data sheets concerning the analysis of the costs of the various installation jobs were filled out. Both the total and the unit costs were calculated in both Nicaraguan currency (Cordoba) and Euro (assuming the exchange rate of 20 Cordobas per Euro current at the time of the works). As mentioned above, we also considered the contribution from the local Community in terms of labour force or materials. The total prices of the works are shown in Fig. 7.

It is interesting to compare the aforementioned costs with those to be met in Italy. To do that, we will refer to the data provided in the Soil bio-engineering Manuals of the Latium Region reports (Regione Lazio, 2006) with regard to the Province of Rome:

- live fascine mattress on slope: $26.83 € / \mathrm{m}$

- live palisade: $28.67 € / \mathrm{m}$

- vegetated live crib wall: $213.90 € / \mathrm{m}^{3}$

- Vegetative covering with biotextile and metallic net: $21.42 € / \mathrm{m}^{2}$

From these data, prices in equal-purchasing-power dollars can be obtained, with regard to both the Nicaraguan and the Italian contexts. A more reliable comparison can then be made. Figure 8 shows the reduction of price divergence as per exchange rate.

We then calculated the ratio between construction costs in Italy and in Nicaragua in order to assess which soil bioengineering effort was quantitatively advantageous within the context of our study. Table 3 shows these values in the two cases of currency exchange mentioned above. As may be noticed, the ratio ranges between 1.5 times (for the vegetative covering) and almost 4 times (for the fascine mattress).

\section{Discussion}

As regards survival rates, the behaviour of Gliricidia sepium and Tabebuia rosea in the live palisade (Figs. 9 and 10) is more than satisfactory: they both showed rooting percentages exceeding $60 \%$ (Lammeraner et al., 2005). We want to point out the exceptional result of Gliricidia sepium, which after 18 months boasted a $100 \%$ survival rate. This confirms the results of a previous study (Petrone and Preti, 2008), which however referred to a different climatic area. While the area of Río Blanco, object of the present study, is classified as humid tropical forest, the area of Léon, object of the previous study, was a dry tropical forest. Therefore Gliricidia sepium shows considerable potential as a species used for soil bioengineering works over a wide range of climatic characteristics. The highly negative result of Erythrina fusca in live palisade (survival rate 14\%) can be attributed to the fact that this species is a hygrophyte. This characteristic, together with planting during the dry season and with the different soil texture of the two sites, can explain the negative result. In confirmation of this, we can point to the survival rate of the same species in the live crib wall for riverbank protection, which was 3 times higher (Figs. 11 and 12). 


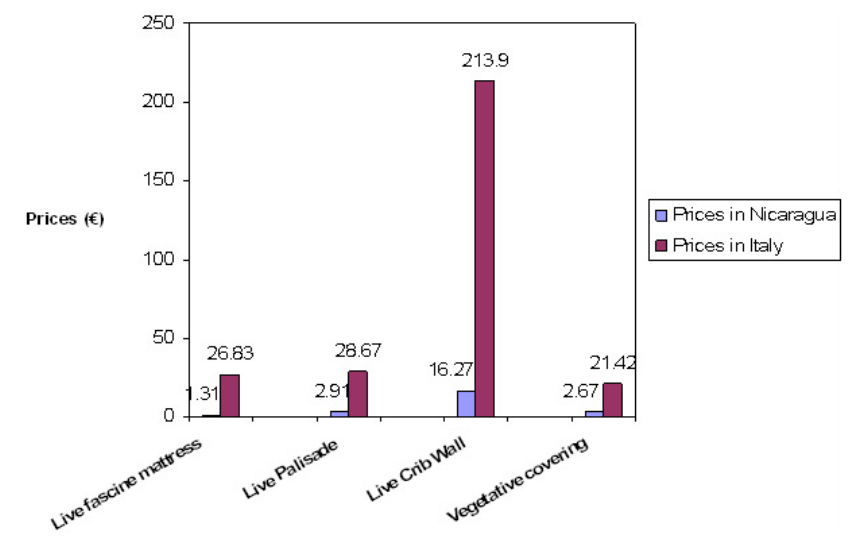

Fig. 7. Comparison between prices in Nicaragua and Italy (official exchange rate).

As far as vegetative development is concerned, Gliricidia sepium once again surpassed the other two species, both in the length and the diameter of the terminal shoots.

Despite this, the behaviour of all three species can undoubtedly be considered satisfactory from the point of view of the trend of the growing rate. We should especially point out the result of Erythrina fusca in its natural habitat (on the banks of waterways): after 18 months from the time of planting all the shoots showed an average length of roughly $3 \mathrm{~m}$ and an average diameter of roughly $5.5 \mathrm{~cm}$.

If these results are compared to the counterpart registered in the palisade for Erythrina fusca (average shoots' length below $90 \mathrm{~cm}$ and average diameter of about $2.2 \mathrm{~cm}$ ), the hypothesis of a connection between the better performance in the bank intervention and the abundance of water is reinforced.

The analysis of the costs of these interventions allowed us to reach greater awareness of the financial sustainability of soil bioengineering in "impoverished" (better than "developing") countries than in previous works (Petrone and Preti, 2005 , 2008), which only considered the realization of vegetated live crib walls compared to classical interventions such as concrete walls and gabions. In contrast, in the present study "lighter" kinds of vegetative covering interventions (vegetative covering with biotextile and metallic net) and stabilizing interventions (live fascines and live palisade) are also included. As showed in Table 3, all the works are more economical in Nicaragua, also considering the EPP exchange rate: in particular two works where the use of manpower and live materials (fascines and vegetated live crib wall) was significant showed themselves to be very advantageous, while the gap is narrower for vegetative covering when bars and wire nets are prevailing costs.

As regards the effectiveness of the proposed technology, we can conclude that it would contribute to slope stabilization with both the short-term objective of land protection and the long-term objective of integrated development.

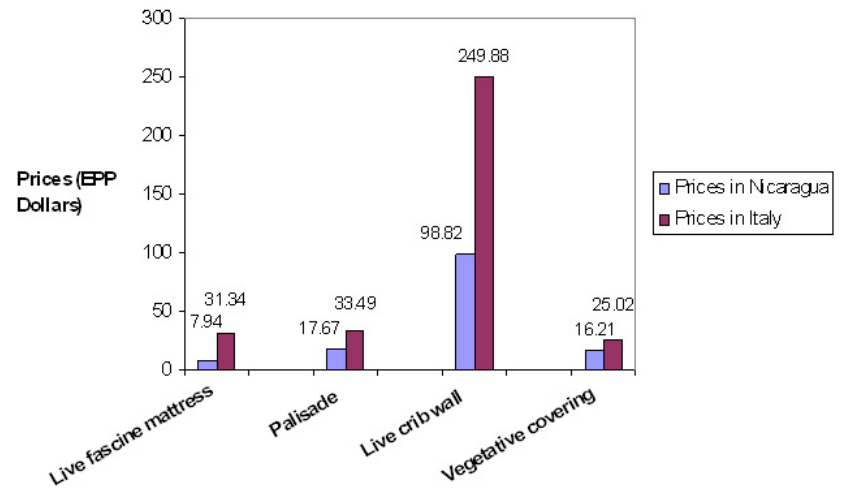

Fig. 8. Comparison between prices in Nicaragua and in Italy (EPP exchange rate).

Assessment of the risk factors which might cause the failure of the technology is essential. First of all, it is quite difficult to define the most appropriate type of intervention, as this greatly depends on the site conditions (botanical, climatological, morphological, etc.; Kuriakose et al., 2009). Moreover, increased efforts to train technical personnel will be needed, as in certain cases professional experience is required. The manageability of the intervention depends on its persuasiveness in a given social context, and is consequently linked to subjective factors going beyond technical analysis. Other important factors include the conditions under which all potential users will operate and the instruments they will use in relation to the needs of new technology. In our case, manageability seems to be the main characteristic of soil bioengineering, and it is the first step of our transferability proposal.

After defining the most suitable intervention type, the realization phase does not seem to present major difficulties, thanks to the ready availability of materials and labour to be used for construction. Our results show that manageability is quite effective in limited interventions, while in larger ones it is fundamental to ensure technical consultation during the first phase.

Since soil bioengineering transfer provides users with an instrument that guarantees stability, it is essential to clearly demonstrate the objectives, risks and reproducibility of the technology to local communities. In this phase, information should be exchanged between users and technicians: local communities should collect necessary information in datapoor regions in order to enable technicians to choose the best configuration (e.g. the most suitable live materials). What is more, public demonstrations and technical courses should be arranged to show the users the new technology (Kuriakose et al., 2009). In the information-gathering phase, users must be informed of all aspects of the technology, including possible risks. One of these is the lack of a database relative to the application of soil bioengineering in impoverished countries, with consequent difficulty in foreseeing definite results (Bruscoli et al., 2001). 


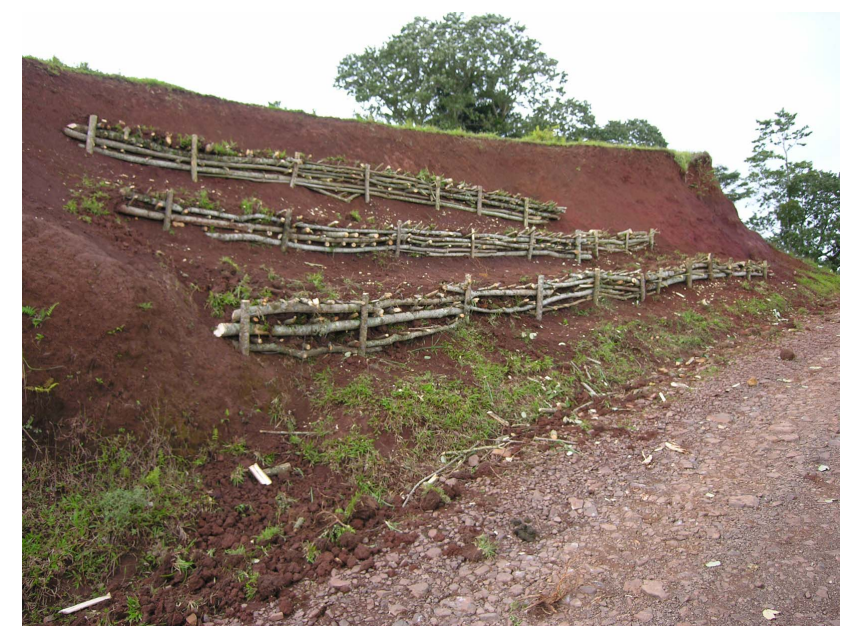

Fig. 9. The live palisade just after construction.

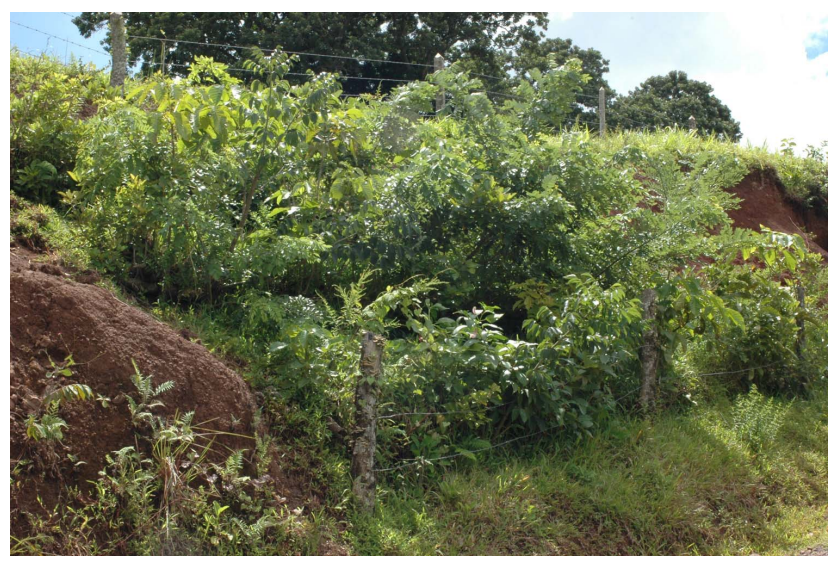

Fig. 10. The live palisade 18 months after construction.

\section{Conclusions}

This present study had the main purpose of addressing the species selection question, which was accomplished by conducting on-site tests on various native species, cuttings of which were applied to several types of rehabilitation works. Among the species used we found that Gliricidia sepium (local common name: Madero negro) and Tabebuia rosea (local common name: Roble macuelizo) are adequate for soil bioengineering measures on slopes, while Erythrina fusca (local common name: Helequeme) reported successful behaviour only in the live crib wall for riverbank protection.

In addition to this kind of investigation, we also wanted to tackle the issue of the financial sustainability of the proposed soil bioengineering activities. Through a rigorous analysis of the various cost entries, some interesting conclusions were reached. Indeed, the Equal Purchasing Power exchange rate allowed us to realize that the costs for carrying out the various engineering jobs were far lower than in Europe.

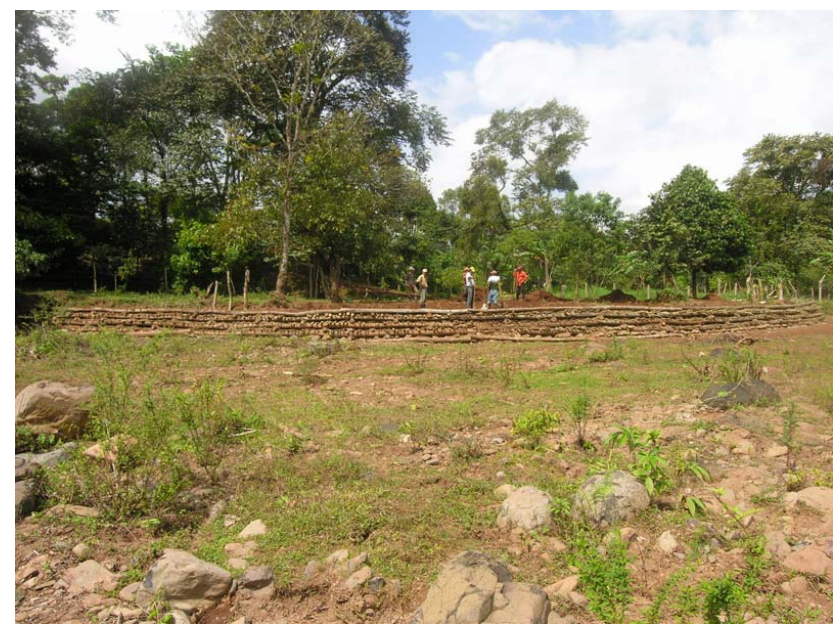

Fig. 11. The vegetated crib wall along Wanawas river just after the construction.

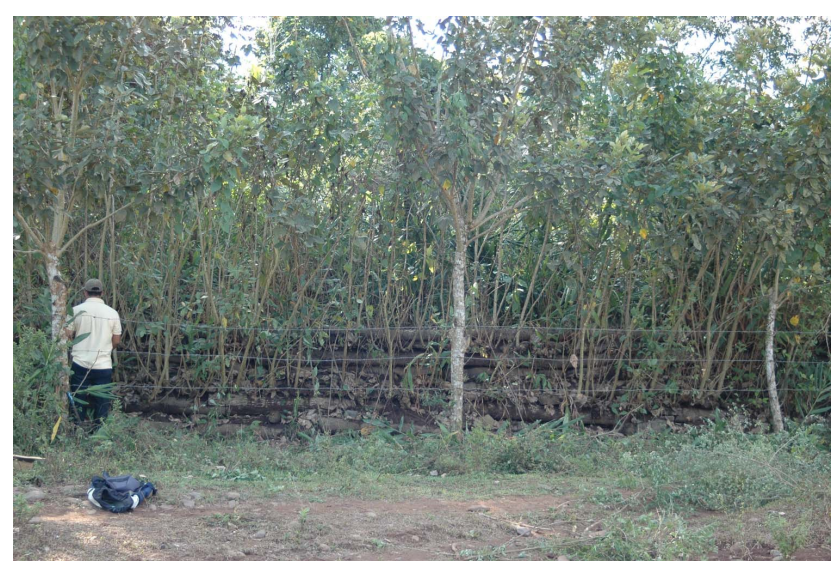

Fig. 12. The vegetated crib wall one year after the construction.

Thus, a conclusion can be reached regarding hydrologicalrisk mitigating actions performed on a basin scale and through naturalistic techniques: not only are they technically possible, even in hardship areas, (by maximizing the contribution of the local labour force and minimizing the use of mechanical equipment), but they are also economically sustainable.

Acknowledgements. The work presented in this paper was performed within the framework of the project "Sistema de prevención antes desatres naturales en 7 comunidades rurales del area del cerro Musún" ("Natural disasters prevention system in 7 rural communities of the Cerro Musún"). This undertaking was introduced by the non-governmental organization COSPE and received the European Union's DIPECHO funds. This research was also partially supported by the Project: PRIN-MIUR (Italian Ministry for University and Research) "Sistemi di monitoraggio e modelli per lo studio dei processi di eco-idrologia a diverse scale spazio-temporali".

Edited by: N. Romano 


\section{References}

Alcaldía Municipal de Río Blanco, SE, SINAPRED, INETER, COSUDE, SNV: Análisis de Riesgos del Municipio de Río Blanco, Managua, Nicaragua, 2005.

AMUNIC-INIFOM: Caracterización municipal de Río Blanco, 2008.

Anaya, G. M., Martinez, M. M. R., Trueba, C. A., Figueroa, S. B., and Fernandez, M. O.: Manual de Conservación de suelos y del agua, Chapingo (Mexico), Colegio de Postgraduados, 581 pp., 1977.

Bostanoglou, L.: Restauration et protection des pentes degradées, Conservation des resources manual, FAO Conservation Guide, 13/1, 1980.

Bruscoli, P., Bresci, E., and Preti, F.: Diagnostic Analysis of an Irrigation System in the Andes Region, Agricultural Engineering International: the CIGR Journal of Scientific Research and Development, III, 1-14, 2001.

Bunch, R. and Lopez, G.: Soil recuperation in Central America: Sustaining Innovation after Intervention, Gatekeeper Series n 55, International Institute for Environment and Development, London, 1999.

Castillo, F. J. A. and Müller-Sämann, K.: Conservación de suelos en ladera: Buscando nuevas alternativas, in: Memorias de un seminario nacional sobre actualización en conservación de suelos en laderas, Centro de estudios para la Conservación Integral de la ladera (CECIL), Santafé de Bogotá, Colombia, 87-106, 1996.

Chambers, R.: Rural appraisal: rapid, relaxed and participatory, IDS pubblications, University of Sussex, England, 1992.

Clark, J. and Hellin, J.: Bio-engineering for Effective Road maintainance in the Caribbean, Natural Resources Institute, The University of Greenwich, UK, 1996.

Clyma, W., Lowdermilk, M. K., and Corey, G. L.: A research development process for improvement of on-farm water management, Water Management Research Project, Colorado State University, Fort Collins, Colorado, USA, 1977.

Costantinesco, I.: Soil conservation for developing countries, FAO Soil Bulletin, 30, 74-86, 1976.

Devkota, B. D, Paudel, P., Omura, H., Kubota, T., and Morita, K.: Uses of Vegetative Measures for Erosion Mitigation in Mid Hill Areas of Nepal, Kyushu J. For. Res., 59, 265-268, 2006.

Dickerson, J. A. and Lake Jr., D. W.: Cost Effective Biotechnical Slope Protection Trials in New York, ASAE, Paper No. 892 654, 1989.

Evette, A., Labonne, S., Rey, F., Liebault, F., Jancke, O., and Girel, J.: History of Bioengineering Techniques for Erosion Control in Rivers in Western Europe, Environ. Manage., 43, 972-984, 2009

Federación Nacional de Cafeteros de Colombia (FEDERACAFÉ), Centro Nacional de Investigaciones de Café (CENICAFÉ) Manual de conservación de suelos de ladera, Chinchiná, Cenicafé, 267 pp., 1975.

Florineth, F.: Stabilization of gullies with soil - bio-engineering methods in the Alps and in Nepal, in: Gully Erosion under Global Change, edited by: Li, Y., Poisen, J., and Valentin, C., Sichuan Science and Technology Press, Chengdu, China, 315339, 2004.
Garrity, D. P., Stark, M., and Mercado Jr., A.: Natural vegetative strips: a bioengineering innovation to help transform smallholder conservation, in: Ground and Water Bioengineering for Erosion Control and Slope Stabilisation, edited by: Barker, D. H., Watson, A. J., Sombatpanit, S., Northcutt, B., and Maglinao, A. R., Science Publishers Inc., Enfield, New Hampshire, 263-270, 2004.

Ghimire, S. K. and Karki, K. K.: Mitigation of soil erosion hazards through bio-engineering: a case study of Mid-Himalaya, Nepal, International Conference Eco-Engineering: "The use of vegetation to improve slope stability", Thessaloniki, 2004.

Gray, D. H. and Leiser, A. T.: Biotechnical Slope Protection and Erosion Control, Van Nostrand Reinold Company, New York, 271 pp., 1982.

Gray, D. H. and Sotir, R. B.: Biotechnical and soil bioengineering slope stabilization, A practical guide for erosion control, New York, John Wiley \& Sons, Inc., 378 pp., 1996.

Hudson, N.: Conservación de suelos, Barcelona (España), Reverté S.A., 335 pp., 1982.

IRENA: Árboles forestales útiles para su propagación, Instituto Nicaragüense de Recursos Naturales y del Ambientes, Managua, Nicaragua, 246 pp., 1992.

Johnson, N., Lilja, N., and Ashby, J.: Measuring the Impact of User Participation in Agricultural and Natural Resource Management Research, Agr. Syst., 78, 287-306, 2003.

Kirby, M. J. and Morgan, R. P. C.: Erosión de suelos, $1^{a}$ edición, México, Limusa S.A., 367 pp., 1984.

Kuriakose, S. L., van Beek, L. P. H., and Westen, C. J.: Parameterizing a physically based shallow landslide model in a data poor region, Earth Surf. Proc. Land., 34(6), 867-881, doi:10.1002/esp.1794, 2009

Lammeraner W., Rauch, H. P., and Laaha, G.: Implementation and monitoring of soil bio-engineering measures at a landslide in the Middle Mountains of Nepal, Plant Soil, 278, 159-170, 2005.

Leach, M., Mearns, R., and Scoones, I.: Environmental entitlements: dynamics and institutions in community-based natural resource management, World Dev., 27(2), 225-247, 1999.

Li, X., Zhang, L. Q., and Zhang, Z.: Soil bioengineering and the ecological restoration of riverbanks at the Airport Town, Shanghai, China, Ecol. Eng., 26, 304-314, 2006.

Marui, H.: Landslide prevention measures, FAO watershed management field manual, FAO naturelles en zones arides et semiarides, Cahiers FAO: Conservation des sols: 115-135, Conservation Guide, 13/4, 135-153, 1988.

Nygren, A.: Community-Based Forest Management Within the Context of Institutional Decentralization in Honduras, World Development Vol. 33, No. 4, 639-655, 2005.

Olivier de Sardan, J.-P.: Anthropology and development: understanding contemporary social change, Zed Books, London \& New York, 2005.

Petrone, A.: Realización de obras de mitigación con técnicas de ingenería naturalistica en el Cerro Musún- Río Blanco, published in the framework of the DIPECHO Project "Sistema de prevención antes desatres naturales en 7 comunidades rurales del area del cerro Musún”, Nicaragua, 2006. 
Petrone, A. and Preti, F.: Ingenieria Naturalistica en Centroamérica, Manuali Tecnici per la Cooperazione allo Sviluppo, Istituto Agronomico per l'Oltremare, Società Editrice Fiorentina, Firenze, 108 pp., ISBN 88-89507-02-0, 2005.

Petrone, A., Matassoni, P., and Preti, F.: Sperimentazioni con talee di specie autoctone in interventi di ingegneria naturalistica in Nicaragua, Quaderni di Idronomia montana, Nuova Editrice Bios, Castrolibero, 26, 477-488, 2006.

Petrone, A. and Preti, F.: Suitability of soil bioengineering techniques in Central America: a case study in Nicaragua, Hydrol. Earth Syst. Sci., 12, 1241-1248, 2008, http://www.hydrol-earth-syst-sci.net/12/1241/2008/.

Preti, F. and Milanese, C.: Monitoring Ground Bio-Engineering Stabilization of Land-Slides in Lazio Region (Italy), in: Ecoand Ground Bio-Engineering: The Use of Vegetation to Improve Slope Stability Proceedings of the First International Conference on Eco-Engineering, 13-17 September 2004, Series: Developments in Plant and Soil Sciences, edited by: Stokes, A., Spanos, I., Norris, J. E., and Cammeraat, E., Springer, Vol. 103, ISBN 10: 1-4020-5592-7, ISBN 13: 978-1-4020-5592-8, 2007.

Preti, F.: Stabilità dei versanti vegetati, Cap. 10, in: Manuale 3 d'Ingegneria Naturalistica Sistemazione dei versanti, Regione Lazio, Roma, edited by: Sauli, G., Cornelini, P., and Preti, F., http://www.regione.lazio.it/web2/contents/ ingegneria_naturalistica/manuale_versanti/Cap_10_10.pdf, last access: February 2010, 2006 (in Italian).

Preti, F.: Seguimiento de de trabajos de Ingenieria Biologica en Italia central, Cuadernos de Arquitectura del Paisaje, 2007.

Preti, F., Dani A., and Laio F.: Root profile assessment by means of hydrological, pedological and above-ground vegetation information for bio-engineering purposes, Ecol. Eng., doi:10.1016/j.ecoleng.2009.07.010, in press, 2010.

Sauli, G., Cornelini, P., and Preti, F.: Regione Lazio, Manuale 3 d'Ingegneria Naturalistica- Sistemazione dei versanti, Regione Lazio, Roma, http://www.regione.lazio.it/web2/contents/ ingegneria_naturalistica, last access: Februar 2010, Ed. Emilmarc s.r.l., Roma, 2006.

Reubens, B., Windey, J., Danjon, F., Poesen, J., and Muys, B.: Root system architecture of woody species important for erosion control in Tigray, Northern Ethiopia, Proceedings 4th International Symposium on Dynamics of Physiological Processes in Roots of Woody Plants, 16-19 September 2007, Bangkor, UK, 2007.

Rivera, H. R. and Sinisterra, J. A.: Uso social de la Bioingeniería para el control de la erosión severa, CIPAV-CVC, 2006.
Schiechtl, H. M.: Vegetative and soil treatment measures, FAO watershed management field, 1985.

Schiess, M. P.: Conception et construction des routes dams les basins versants sensibles, Guide pratique d'aménagement des bassins versants, Cahier FAO Conservation, 13/5, 155-172, 1994.

Sheng, T. C.: Approche d'aménagement intégré dans l'etablissement d'un projet de développement d'un bassin versant, Aménagement des bassins versants, Cahier FAO: Conservation des sols, 1, 11-18, 1977.

Sheng, T. C.: Protection des versant cultivés, Aménagement des basins versants, Cahier FAO: Conservation des sols, 1, 179-213, 1977.

Sheng, T. C.: L'ensemencement par pulvérisation: procédés, exemples et perspectives a la Jamaique, Techniques spéciales de conservation, Cahier FAO: Conservation des sols, 4, 75-83, 1979.

Sheng, T. C.: Watershed survey and planning, Watershed management field manual, FAO Conservation Guide, 13/6(3-15), 132140, 1990.

Suarez Diaz, J.: Control De Erosion en Zonas Tropicales, ISBN 958-33-2734-4, 2001

Sutili, F. J., Durlo, M. A., and Bressan, D. A.: Bio-technical capability of "sarandi-branco" (Phyllanthus sellowianus mull. Arg.) and "vime" (Salix viminalis L.) for re-vegetation water corse edges, Ciencia Florestal, Santa Maria, Brasile, 14(1), 13-20, ISSN 0103-9954, 2004.

UNDP (United Nations Development Programme): Lo sviluppo umano rapporto 2006- L'acqua tra potere e povertà, Legoprint, Lavis (Trento), 494 pp., ISBN 88-7885-099-3, 2006.

van Beek, L. P. H., Wint, J., Cammeraat, L. H., and Edwards, J. P.: Observation and simulation of root reinforcemente on abandoned Mediterranean slopes, Plant Soil, 278, 55-74, 2005.

Vishnudas, S., Savenije, H. H. G., Van der Zaag, P., Anil, K. R., and Balan, K.: The protective and attractive covering of a vegetated embankment using coir geotextiles, Hydrol. Earth Syst. Sci., 10, 565-574, 2006, http://www.hydrol-earth-syst-sci.net/10/565/2006/.

Wikipedia: http://upload.wikimedia.org/wikipedia/commons/c/c0/ Nicaragua_rel_97.jpg, last access: 28 July 2009.

Wilken, G. C.: Good Farmers: Traditional Resource Management in Mexico and Central America, UC Press, Berkeley, CA, 1987.

Zanoni C.: Ritorno al passato, una viminata spondale realizzata dagli aztechi, ACER, 6, 61-63, 2009 (in Italian). 